\title{
Estimates of Economic Cost of Congestion Travel Time Delay Between Onne- Seaport and Eleme-Junction Traffic Corridor
}

\author{
Theophilus C. Nwokedi ${ }^{1 *}$, Lazarus I. Okoroji ${ }^{2}$, Ifiok Okonko ${ }^{1}$ and Obed C. Ndikom ${ }^{1}$ \\ ${ }^{1}$ Federal University of Technology, Department of Maritime Management Technology, Owerri, \\ Nigeria; Email:nwokeditc@gmail.com,ifiokonko@gmail.com, \\ bonmilnigerialimited@yahoo.com \\ ${ }^{2}$ Federal University of Technology, Department of Transport Management Technology, Owerri, \\ Nigeria; Email: okorojili@yahoo.com
}

*Corresponding Author: Theophilus C. Nwokedi

Received: 25 August 2020; Revised: 23 September 2020; Accepted: 27 September 2020; Published: 30 November 2020

\begin{abstract}
Travelers along the Onne-seaport to Eleme-junction road corridor in the hub of the oil and gas industry in Port-Harcourt, Nigeria, have continued to experience very serious traffic congestion travel time delays, culminating into loss of man-hours and declining productivity. This study estimated the economic cost of traffic congestion travel time delay along the corridor, with a view to providing economic justification for developing traffic management policies and road infrastructure, to remedy it. A mixed research approach was adopted in which data was sourced through field survey and from secondary sources. The gross output model was used to estimate the output losses occasioned by productive time losses related to traffic congestion. The study established that the average daily traffic congestion travel time delay along the traffic corridor by travelers in trucks, car, bus and taxi modes are 104.17 minutes, 46.60 minutes, 58.5 minutes and 56.4 minutes respectively. The estimated daily aggregate economic cost of output losses associated with traffic congestion time delay on the corridor is 46049809.8 naira (210923.5USD) for all modes. This justifies any investment in traffic congestion remedial strategies along the route.
\end{abstract}

Keywords: Economic-cost, traffic-congestion, travel-time, delay, corridor

\section{Introduction}

Travelers along the Onne-seaport to Eleme junction road corridor in the oil and gas free zone, PortHarcourt, Nigeria, have continued to face challenges of traffic congestion associated with poor road 
conditions and increasing demand for transportation within the Port-Harcourt Megalopolis, and the sub-urban link roads [1]. The current traffic congestion challenges on the route are viewed as associated with inadequacy in capacity supply relative to the demand for use of the road infrastructure.

Traffic congestion represents a condition of traffic overcrowding or overburdening, in which the number of motor vehicles seeking access to the use of a given section of the road infrastructure, at a particular point in time, is far greater than the capacity of the infrastructure; as result of which the available infrastructure cannot simultaneously meet the demand for services, leading to a situation of traffic gridlock, in which motorist fight for access to use of the road simultaneously [2-4].

Justifying investment in road infrastructure cum traffic management policies to curtail traffic congestion challenges along the route demands the measurement of the output losses occasioned by traffic congestion travel time delay. The lost travel time component induced by traffic congestion can be viewed as the productive time which an individual traveler would have used to produce a reasonable output. There exists relationship between the output of an individual in an economy, measured by per capital output (gross output), and the productive time spent in producing the output. Thus, traffic congestion travel time delay, induces output losses equivalent to the output corresponding to what would have been produced, if the travel time delays, were employed for active productive activities [510]. The European Union puts the average marginal cost of congestion for 2010 at $£ 0.487$ / vehiclekilometer in near capacity traffic conditions [11,12]. More studies such as the works of [13-15] also estimated the economic cost of traffic congestion for purposes of justifying investment in traffic congestion mitigation measures using the opportunity cost approach. Since an individual's output has a relationship with the official productive hours; this relationship offers a sound empirical base for estimating the value of output losses related to traffic congestion travel time delay [16-18].

Given the importance of the road corridor to the Nigerian economy and global oil and gas logistics sector, the need to estimate the economic cost of traffic congestion travel time delay along the route with a view to seeking justification for investment in traffic congestion remedial measures along the route is the central objective the study. The study will also determine the major intersection along the travel route that is most prevalent with traffic congestion risks, for purposes of prioritizing investment in remedial actions.

\section{Data and Methods}

Secondary data on per capital output was sourced from the Central bank of Nigeria (CBN). Primary data was sourced using survey. Survey questionnaire was structured to elicit responses from road users on their travel time experiences on the route, during congested and free flow traffic conditions. To limit 
error, the survey was carried out for two different days of two weeks interval. In each day, three periods of traffic count were carried out; the traffic condition in morning peak hours (7.0 am to 10.30 am), afternoon hours (11.30 am to $3.00 \mathrm{pm}$ ) and lastly evening peak hours (from $3.30 \mathrm{pm}$ to $6.0 \mathrm{pm}$ ). Various components of travel time experiences of the road users were determined as:

(i) The time (in minutes, hours or seconds) it takes the road user to travel from Onne seaport to Eleme junction in a free flow traffic condition (Free flow travel time $=F_{n}$ ).

(ii) The time it takes each road user to travel from Onne seaport to Eleme junction in a congested traffic situation and/or traffic gridlock (Traffic Gridlock travel time $=\mathrm{G}_{\mathrm{c}}$ ).

\subsection{Population Covered by the Survey and Sample Size}

The national population commission (NPC) put the projected population of the people living Eleme industrial zone where the study was based at 267,200. We used the population of Eleme that access work locations in the area and Port-Harcourt City as identified above to constitute the population of the study, from which sample was randomly selected using Taro Yamane (1973) formula for calculating sample size for a known population is given as:

$$
n=\frac{N}{\left(1+N(e)^{2}\right.},[\mathrm{n}]
$$

where: $n$ is sample size required for the survey [persons]; $N$ is the population size [persons]; $e$ is margin error [\%].

Approximately 400 road users constituting of passengers, private car users and truck drivers and other categories of drivers were sampled. However, only 280 copies of the sample questionnaire distributed representing about $70 \%$ were returned.

\subsection{Methods of Data Analysis}

The traffic congestion travel time delay along the route was estimated as the difference between travel time during free flow condition and travel time experiences during traffic congestion and/or gridlock. That is:

$$
T_{t d}=G_{c}-F_{n},[\mathrm{~s}]
$$

where: $T_{t d}$ is traffic congestion travel time delay experiences of road users [s].

Generally, where multiple members of the working population (e.g.: $P_{1}, P_{2}, P_{3}=P_{w}$ ) are subjected to varied and/or disproportionate amounts of traffic congestion delay, leading to losses of productive time, the aggregate productive time lost due to traffic congestion is expressed as: 


$$
T_{\text {tdaggregate }}=\sum_{\mathrm{n}=1}^{\mathrm{P}}\left(T_{t d} P_{1}+T_{t d} P_{2}+T_{t d} P_{3}\right),[\mathrm{s}]
$$

We assume that it takes travelers in the same mode (e.g., taxi, truck, motorcycle, car, etc, ) averagely the same travel time to travel between the two points in a free flow traffic condition $\left(F_{n}\right) ; \mathrm{P}=$ populations involved in traffic congestion time delay, $P_{w}=$ aggregate number of working population that experienced traffic congestion time delay, $T_{t d} P_{l}=$ travel time delay experience of the first single member of the working population $P_{1}$.

Similarly, when multiple members of the working population (e.g: $P_{1}, P_{2}, P_{3}=P_{w}$ ), face proportionate levels of traffic congestion time delay and productive time losses, the total productive time lost, is the product of the travel time delay suffered by a single member of the population and the total number of members of the working population that experienced the same traffic congestion time delay. For proportionate travel time delay faced by multiple members of population, we write that:

$$
T_{\text {tdaggregate }}=P_{w}\left(T_{t d}\right)=T_{t d} P_{w}-,[\mathrm{s}]
$$

We used the gross output approach, used by World Health Organization (WHO, 2012) to model output losses of injury induced idle time, viewed as productive time lost due to hospitalization; to estimate the economic cost of traffic congestion travel time delay on the route.

\subsubsection{Gross Output/ Per Capital Output (Y) approach Estimation of Economic Cost of Traffic Congestion Travel Time Delay}

The gross output approach of the per capital output model offers a human capital perspective of determining economic estimates of traffic congestion travel time delay. It views the economic cost of traffic congestion travel time delay as equivalent to the value of output which the victim of traffic congestion travel time delay, would have contributed to the economy, if he was not delayed in traffic. With standard working hours per day in Nigeria as 8 hours, from 8.0 am to $4.0 \mathrm{pm}$, for Government works; and about 10 hours (from 8.0 am to $6.0 \mathrm{pm}$ ) for private businesses; excluding Sundays and Saturdays which are work free days for many categories of public servants. There are about s52 working weeks of 260 working days per year. The ratio of the per capital output to the number of working days per year yields the average daily output per population.

Thus we write that value of daily output per capital is:

$$
V D O P=\frac{Y}{W},\left[\frac{U S D}{d a y}\right]
$$

where: $Y$ is gross per capital output [USD]; $W$ is working days per annum (excluding weekend, Saturdays and Sundays, holidays $=260$ days of 52 weeks) [days]. 
This is true as long as the value of the national annual per capital output (Y) is dependent on the daily output of the working population.

The economic cost of output lost per unit of travel time delay per capital (per population) is the ratio of value of daily output per population $(V D O P)$ to the standard daily working hours $\left(T_{h r s}\right)$.

That is Output per Unit productive Time per population $(O P T P)$ :

$$
O P T P=\frac{V D O P}{T_{h r s}} \rightarrow=\frac{Y}{W} * \frac{1}{T_{\square r s}},\left[\frac{\text { time }}{\text { capital }}\right]
$$

where: OPTP is estimate of the economic value of output per unit productive time (minute/hour/seconds) per capital; $T_{h r s}$ is standard daily working time [s].

Note for public servants $T_{h r s}=8$ hours $=480$ minutes productive time (man-hours) per day. For Private businesses is $T_{h r s}=10$ hours per day $=600$ minutes productive time per day. In an economy having both private businesses and public service worker which is usually the case in most economies, $T_{h r s}$ is taken as average of the two $=9.5$ hours $=570$ minuts productive time per day.

Using equation (6) we established a relationship between output per unit productive time per population $(O P T P)$ and a unit traffic congestion time delay $\left(T_{t d}\right)$ in hours or minutes or seconds experienced per population, such that, the product of OPTP and $T_{t d}$ gives the economic estimate of output lost per unit time delay.

That is:

$$
E C T_{t d}=\quad T_{t d}\left(\frac{V D O P}{T_{\square r s}}\right) \rightarrow T_{t d}\left(\frac{Y}{W} * \frac{1}{T_{\square r s}}\right),[-]
$$

where: multiple members of the working population $(P w)$ experienced proportionate traffic congestion time delay, the total economic cost of output lost by the economy is estimated as:

$$
E C T_{\text {tdaggregate }}=\left[\left(P_{w}\right) T_{t d}\left(\frac{Y}{W} * \frac{1}{T_{\square r s}}\right)\right],[-]
$$

where: $P w$ is number of members of the working population that experienced congestion travel time delay. Using equations - (7) and - (8), we estimated the economic cost of traffic congestion time delay along Onne-seaport to Eleme junction traffic corridor.

\section{Presentation of Data}

Table 1 shows that a total of 281 people representing about $70 \%$ of the sampled population properly filled and returned the survey questionnaire. Of this number, 64 were road truck operators, 78 travel by car mode, and 62 travel by bus mode while 77 travel by taxi. The survey result as shown above indicate that the average travel time during free flow $\left(F_{t}\right)$, when there is no traffic congestion and/or gridlock 
along the 22 kilometer Onne-seaport to Eleme Junction road varies for the individual modes. It takes an average of 34.17 minutes for road trucks, 26.4 minutes for cars, 32 minutes for bus mode and 29 minutes for the taxi mode. Similarly, the average travel time in a traffic congestion and/or gridlock condition along the route for the various modes of truck, car, bus and taxi is 138.3 minutes, 73 minutes, 90 minutes and 85 minutes respectively.

Table 1 Mode specific free flow travel time, gridlock travel time, frequency of congestion and distance of Onne seaport to Eleme Junction Traffic Corridor. Source: authors

\begin{tabular}{|c|c|c|c|c|c|c|c|c|c|}
\hline \multirow[t]{2}{*}{$\begin{array}{l}\text { Travel } \\
\text { Mode }\end{array}$} & \multirow{2}{*}{$\begin{array}{l}\text { No. of } \\
\text { respondent } \\
\mathrm{s}\end{array}$} & \multirow{2}{*}{$\begin{array}{l}\text { Average } \\
\text { Gc } \\
\text { (minutes) }\end{array}$} & \multirow{2}{*}{$\begin{array}{l}\text { Average } \\
\text { Ft } \\
\text { (minutes) }\end{array}$} & \multirow{2}{*}{$\begin{array}{l}\text { Frequency } \\
\text { of } \\
\text { congestion } \\
\text { experience }\end{array}$} & \multirow{2}{*}{$\begin{array}{l}\text { Travel } \\
\text { Distance } \\
(\mathrm{km})\end{array}$} & \multicolumn{3}{|c|}{$\begin{array}{l}\text { Most } \quad \text { congestion } \\
\text { intersection/junction/location }\end{array}$} & \multirow{2}{*}{\begin{tabular}{l}
\multicolumn{1}{r}{ prone } \\
$\begin{array}{l}\text { Indorama } \\
\text { /Bridge }\end{array}$
\end{tabular}} \\
\hline & & & & & & Akpajo & Refinery & $\begin{array}{l}\text { Trailer } \\
\text { park }\end{array}$ & \\
\hline Truck & 64 & 138.3 & 34.17 & weekly & 22 & 34 & 6 & 2 & 22 \\
\hline Car & 78 & 73 & 26.4 & weekly & 22 & 47 & 10 & 0 & 21 \\
\hline Bus & 62 & 90 & 32 & weekly & 22 & 31 & 12 & 3 & 16 \\
\hline Taxi & 77 & 85 & 29 & weekly & 22 & 46 & 5 & 0 & 26 \\
\hline & 281 & & & & & 158 & 33 & 5 & 85 \\
\hline
\end{tabular}

All the respondents expressed that they experience traffic congestion along the route each week. While 158 respondents identified Akpajo Junction as the most congestion prone intersection along the route and the point where they experienced the most of the traffic gridlock, this is followed by petrochemical/Indorama/bridge with 85, Refinery Junction with 33 and lastly Trailer park with 5. Table 1 above is used for further analysis in subsequent pages.

Table 2 Traffic flow condition/data along the road corridor and economic measures of output.

Source: authors

\begin{tabular}{|c|c|c|c|c|c|c|}
\hline \multirow{2}{*}{$\begin{array}{l}\text { Travel } \\
\text { mode }\end{array}$} & \multirow{2}{*}{$\begin{array}{l}\text { Average time } \\
\text { for } 100 \text { vehicle } \\
\text { flow }\end{array}$} & \multirow[t]{2}{*}{ No. Vehicles } & \multirow{2}{*}{$\begin{array}{l}\text { Traffic flow per } \\
\text { unit } \\
\text { (minute) }\end{array}$} & \multirow{2}{*}{$\begin{array}{l}\text { Estimated } \\
\text { human traffic } \\
\text { per minute by } \\
\text { mode }\end{array}$} & \multicolumn{2}{|c|}{ Per capital output (Y) } \\
\hline & & & & & USD & $\mathrm{N}$ \\
\hline Truck & 8 minutes & 12 & 2 & 4 & 2028.18 & $730,152.18$ \\
\hline Car/Taxi & 8 minutes & 77 & 10 & 300 & 2028.18 & $730,152.18$ \\
\hline Taxi & 8 minutes & - & - & - & 2028.18 & 730.152 .18 \\
\hline Bus & 8minutes & 11 & 1 & 10 & 2028.18 & $730,152.18$ \\
\hline All mode & 8 minutes & 100 & $\begin{array}{l}13 \text { vehicles } \\
\text { minute }\end{array}$ & $\begin{array}{l}314 \text { persons per } \\
\text { minute }\end{array}$ & - & - \\
\hline
\end{tabular}

Recall that the survey method used for the study involved a traffic count which was carried out for two days within an interval of two weeks to limit error associated with the used of single day traffic data. In each day, traffic count was carried out in the peak hours of the morning between 7. - 10.30 am, off-peak period of the afternoon between $12.00-3.30 \mathrm{pm}$ and in the peak period of the evening after close of work between $3.30-6.00 \mathrm{pm}$. The average traffic flow rate was determined based on the data collected over the two days field work as shown in table 2 above. The table shows a traffic flow rate of 
an average of 100 vehicles in every 8 minutes time past. This consists of 12 trucks, 77 cars / taxis and 11 passenger buses in every 8 minutes time past. The traffic flow per unit of time is an average of 13 vehicles in all modes per minute.

The mode specific traffic flow condition is 2 trucks per minute, 10cars/taxis per minute and 1 passenger bus per minute. The estimated labour flow (flow of travelers) is 314 persons (productive workforce) per minute. The mode specific flow of travelers along the route per unit time is an average of 4 persons by truck per minute, 300 travelers per minute by car/taxi, and an average of 10 persons per minute by bus mode. The table also shows the year 2018 per capital output of Nigeria sourced from secondary sources as 2028.18 USD equivalent of 730152.18 naira.

\section{Results and Discussion}

The result on Table 3 shows that the gap between gridlock travel time and free flow travel time which indicates the traffic congestion travel time delay for the identified travel modes of truck, car, taxi and bus are 104.13 minutes, 46.600 minutes, 56.40 minutes and 58.50 minutes respectively, with respective standard errors of 28.94, 12.20, 15.60 and 30.00. The implication of this to travelers along this road corridor is that, when exposed to traffic congestion on the traffic corridor, truck operators spend 104.17 minutes approximately $2 \mathrm{hrs}$ more than under a normal free flow traffic condition. This represent the productive man-hours lost while being trapped in traffic congestion related idle time. Travelers by car, taxi and bus modes spend averages of 46.6 minutes, 56.4 minutes and 58.5 minutes more than in normal free flow traffic conditions. These represent productive times and/or man-hours lost as a result of traffic congestion.

Table 3 Determining the travel time delay $\left(T_{t d}\right)$ experience of travelers in various modes.

Source: authors

\begin{tabular}{lllllll}
\hline Mode & $\mathrm{N}$ & $\begin{array}{l}\text { Mean } F_{t} \\
\text { (minutes) }\end{array}$ & $\begin{array}{l}\text { Mean } G_{c} \\
\text { (minutes) }\end{array}$ & $\begin{array}{l}\text { Difference of } \\
\text { means }=T_{t d} \\
\text { (minutes) }\end{array}$ & $\begin{array}{l}\text { \% increase in } \\
\text { travel time }\end{array}$ & Std error \\
\hline Truck & 64 & 34.17 & 138.3 & 104.13 & 305 & 28.94 \\
\hline Car & 78 & 26.4000 & 73.00 & 46.600 & 176.6 & 12.200 \\
\hline Taxi & 62 & 29.00 & 85.40 & 56.400 & 195 & 15.60961 \\
\hline Bus & 77 & 32.00 & 90.00 & 58.50 & 182.8 & 30.00139 \\
\hline
\end{tabular}

By implication, traffic congestion along this corridor increases travel time by $305 \%, 176.6 \%$, $195 \%$, and $182.8 \%$ respectively for truck, car, taxi and bus modes. This has implications on the output of the travelers and the national Gross Domestic product (GDP). It equally reduces the tax earnings of Government both at the local, state and Federal level because the gross output of individuals is the 
basis for determination of their tax burdens. Therefore when the gross output of individuals decline relative to productive time (man-hour) losses occasioned by traffic congestion delay; tax revenues of government will certainly decline.

\subsection{Estimating the Economic Cost of Congestion Travel Time Delay along Onne-Seaport to Eleme Junction Traffic Corridor}

Recall that equation (7) is used for estimating the economic cost or value of output losses related to traffic congestion travel time delay. From the survey result above, it is clear that there are disproportionate delay experiences by trucks, cars, buses and taxis. However, we assume all taxis experienced proportionate delay, and similarly for trucks, cars and buses. Thus equation (7) can be used to determine the value of output losses associated with travel time delay for the various travel modes.

$$
E C T_{t d}=\quad T_{t d}\left(\frac{V D O P}{T_{h r s}}\right) \rightarrow T_{t d}\left(\frac{Y}{W} * \frac{1}{T_{h r s}}\right)
$$

Note: $\mathrm{W}=260$ working days per annum excluding Saturdays and Sundays. (ii) $\mathrm{T}_{\mathrm{hrs}}=9.5 \mathrm{man}$ hours per day $=570$ minutes. (iii) 2018 GDP per capital $\mathrm{Y}=2028.2 \mathrm{USD}=\mathrm{N} 730,152$ @ 360 naira to 1USD exchange rate.

Table 4 Economic cost of Travel time delay of traffic Congestion. Source: authors

\begin{tabular}{|c|c|c|c|c|c|}
\hline \multirow{2}{*}{$\begin{array}{l}\text { Travel } \\
\text { Mode }\end{array}$} & \multicolumn{2}{|c|}{ (currency per unit) } & \multirow{2}{*}{$\begin{array}{c}\boldsymbol{T}_{\boldsymbol{t} \boldsymbol{d}} \\
\text { (minutes) }\end{array}$} & \multicolumn{2}{|c|}{$\frac{Y}{W} * \frac{1}{T_{h r s}}$ (output/unit time) } \\
\hline & \$ (USD) & $\mathrm{N}$ (naira) & & USD/minute & $\mathrm{N} /$ minute \\
\hline Truck & 1.46 & 513.56 & 104.17 & 0.014 & 4.93 \\
\hline Car & 0.65 & 229.7 & 46.600 & 0.014 & 4.93 \\
\hline Bus & 0.819 & 288.40 & 58.500 & 0.014 & 4.93 \\
\hline Taxi & 0.79 & 274.05 & 56.400 & 0.014 & 4.93 \\
\hline
\end{tabular}

The result as shown in table 4 above indicate that for every single minute spent in traffic congestion along the Onne-seaport to Eleme Junction traffic corridor in 2018, the economic value of output lost per individual traveler is 0.014 USD, an equivalent of 4.93 Nigerian naira. Thus, given the disproportionate travel time delay experiences of travelers in the various modes; the average economic cost of individual road truck users trapped in traffic gridlock along the route for an average period of 104.17 minutes is 1.46 USD, an equivalent of 513.56 naira. The economic cost of congestion related travel time delay of the car, bus and taxi modes with respective average travel time delays of 46.600, 58.500 and 56.400 are 229.9naira (0.65USD), 288.40 naira (0.82USD) and 274.05 naira (0.79USD) 
respectively. These represent the economic cost of output losses per capital; that is, per individual member of population involved in traffic congestion time delay in the various modes.

As can be deduced from the table, the economic loss per unit of time (minutes) is the same for travelers in all modes, since the gross output model for traffic congestion loss estimation in line with the national per capital output data, assume a uniform per capital output for all members of the population. It is also important to note that the number of working days and daily work hours remain the same for travelers in all modes. It is obvious from the result of the analysis that travelers' using the truck modes suffers the biggest output losses because of their higher congestion related travel time delay experiences. This is followed by the bus mode, the taxi mode and lastly the car mode.

The policy implication is that, to increase the volume of government revenue earnings from income and employment taxes, national productivity and output, investment must be made to improve traffic management policies, programmes, and the road infrastructure along the corridor, in order to eliminate traffic congestion related travel time delays. Eliminating traffic congestion travel time delay will subsequently ensure that productive man-hours are not wasted in traffic gridlock along the route.

Table 5 Aggregate Economic cost of involvement of multiple members of the working population in traffic congestion based on the traffic flow data of the road corridor.

Source: authors

\begin{tabular}{|c|c|c|c|c|c|c|c|c|}
\hline \multirow[t]{2}{*}{$\begin{array}{l}\text { Travel } \\
\text { mode }\end{array}$} & \multirow[t]{2}{*}{$\begin{array}{l}\text { Traffic } \\
\text { flow per } \\
\text { unit time } \\
\text { (minutes) }\end{array}$} & \multirow{2}{*}{$\begin{array}{l}\text { Estimated } \\
\text { human } \\
\text { traffic } \\
\text { carried per } \\
\text { minute }\end{array}$} & \multirow[t]{2}{*}{$\begin{array}{l}\text { Daily } \\
\text { vehicular } \\
\text { traffic } \\
\text { flow }\end{array}$} & \multirow{2}{*}{$\begin{array}{c}\text { Daily } \\
\text { human } \\
\text { traffic } \\
\text { carried } \\
\left(H_{d}\right)\end{array}$} & \multicolumn{2}{|c|}{$\begin{array}{l}\text { Economic cost per } \\
\text { minute delay }= \\
{\left[H_{d} *\left(\frac{\boldsymbol{Y}}{\boldsymbol{W}} * \frac{\mathbf{1}}{\boldsymbol{T}_{\boldsymbol{h r s}}}\right)\right]}\end{array}$} & \multicolumn{2}{|c|}{$\begin{array}{c}\text { Economic of congestion } \\
\text { travel time delay }= \\
\boldsymbol{E} \boldsymbol{C} \boldsymbol{T}_{\boldsymbol{t} \boldsymbol{d}} * H_{d}\end{array}$} \\
\hline & & & & & USD & $\mathrm{N}$ & USD & $\mathrm{N}$ \\
\hline Truck & 2 & 4 & 1140 & 2280 & 31.92 & 11240.4 & 3328.8 & 1170916.8 \\
\hline $\begin{array}{l}\text { Car / } \\
\text { taxi }\end{array}$ & 10 & 300 & 5700 & 171000 & 2394 & 843030 & 67545.7 & 43070625 \\
\hline Bus & 1 & 11 & 570 & 6270 & 87.78 & 30911.1 & 140049 & 1808268 \\
\hline $\begin{array}{c}\text { All } \\
\text { modes }\end{array}$ & 13 & 314 & 7410 & $\begin{array}{l}178,98 \\
0\end{array}$ & 2513.7 & 885181.5 & 210923.5 & 46049809.8 \\
\hline
\end{tabular}

The result shows that the traffic congestion related delay per minute affecting an estimated 7410 vehicles of multi mode types and about 178,980 daily human traffic flow induces aggregate output losses of 2513.7 USD equivalent to 885181.5 naira per minute. Also, given the disproportionate travel time delay experiences of travelers in various modes as shown in previous tables, the aggregate economic cost of travel time delay experiences of estimated 2280, 171000, and 6270 respective daily travelers by truck, car/taxi, and bus modes are 1170916.8 naira (3328.8 USD), 43070625 naira (67545.7 USD) and 1808268 naira (140049 USD) respectively. The aggregate economic cost of traffic congestion travel time delay for all modes is 46049809.8 naira (210923.5 USD). Given the near daily 
and/or weekly occurrence of traffic congestion on this road corridor as the survey data revealed, the annual cost of the congestion menace is certainly enormous and justifies any investment in remedying the problem.

It also impact on government taxes and revenue and on the overall economy of the state and nation. Investment in traffic management programmes and road infrastructure supply along the corridor is urgently necessary to reverse the trend. Such investments in consideration of the scarce nature of resources should prioritize intersections and junctions that pose the highest level of traffic congestion risk along the road corridor as identified in the result of the survey. See figure1 below.

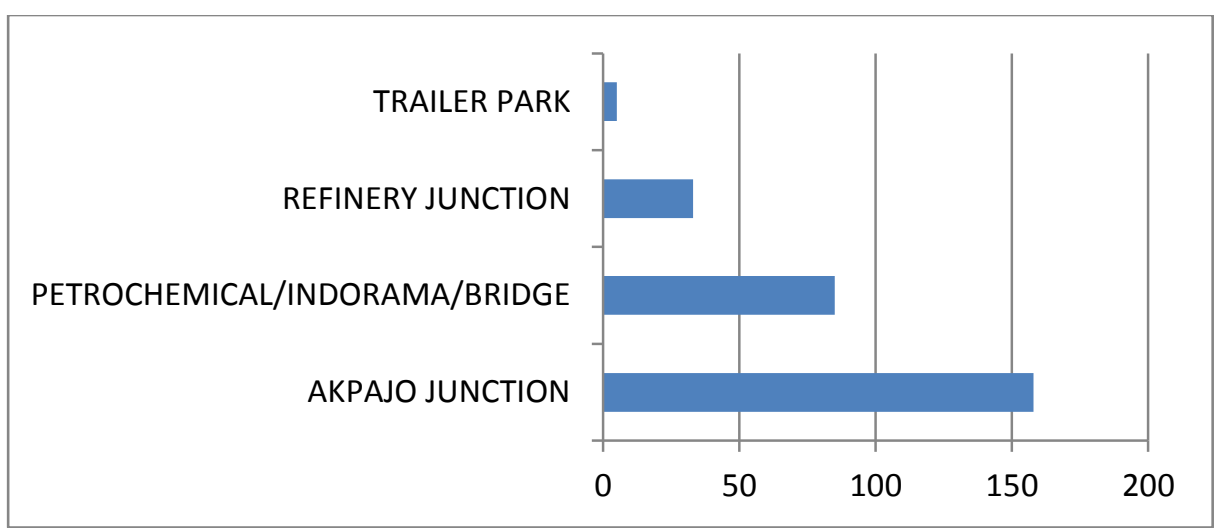

Fig. 1 Ranking of intersections along the corridor in decreasing order of exposure of travelers to travel time delay. Source: authors.

From Figure 1 above, we infer that Akpajo junction should be prioritized for investment traffic congestion remedial along the road corridor. This should be followed by petrochemical/Indorama/bridge, refinery junction and lastly trailer park, in that order.

\section{Conclusion}

In line with the objectives of study, the average traffic congestion related travel time delay experienced by travelers along the Onne-seaport to Eleme junction traffic corridor by users of truck, car, bus and taxi modes are 104.17 minutes, 46.60 minutes, 58.5 minutes and 56.4 minutes respectively. The estimated daily aggregate economic cost of output losses associated with traffic congestion time delay on the traffic corridor is 46049809.8 naira (210923.5USD) for all modes.

\section{References}

[1] OGFZA, (2016). List of clients in the Onne oil and gas Free zone, Retrieved July 23, 2018, from http//www.ogfza.gov.ng.

[2] Alberto, B. (2004). Traffic congestion the problem and how to deal with it. Retrieved November 
23, 2019, from http://www.researchgate.net/publications.

[3] European Commission, (2013). Together towards competitive and resource-efficient urban mobility, 2013 (913). Brussels: European Commission.

[4] Ukpata, J. \& Etika, A. (2012). Traffic congestion in major cities of Nigeria. International journal of engineering and technology 2(8), 1433-1438.

[5] Ortúzar, J.D. \& Willumsen, N. (1994). Modelos de demanda de transporte, Santiago, Chile, Department of Transport Engineering, Catholic University of Chile. Retrieved November 23, 2019, from http://www.researchgate.net/publications.

[6] Rietveld, P. \& Daniel, V. (2004). Determinants of bicycle use: do municipal policies matter? Transportation research part A: policy and practice 38(7), 531-550. DOI: 10.1016/j.tra.2004.05.003

[7] Ian, W. (2013). The cost of congestion reappraised, Report 489, New Zealand Transport Agency. Retrieved November 23, 2019, from http://www.Nzta.govt.nz/resources/research/report/489.

[8] Adebiyi, K.A. (2008). Estimation of air traffic accident cost in Nigeria. Pacific Journal of Science and Technology 9(2), 420-425.

[9] Dale, S. (March, 2017). Evaluating the impacts of traffic congestion on business investment following the introduction of a workplace parking levy and associated transport improvements. Dissertation thesis submitted in partial fulfillment of the requirements for the award of the degree Doctor of Engineering (EngD), at Loughborough University.

[10] Gavanas, N., Anastasios, T. \& Magda, P.L. (2017). Assessment of the marginal cost due to congestion using the speed flow function. Transportation research procedia 24, 250-258.

[11] Sougata, M. (2017). Traffic congestion and possible solutions A case study of Asansol. Journal of research in humanities and social science 5(9), 42-46.

[12] Diw, E., Cau R.-AEA (2014). Update of the handbook on external costs of transport. Final Report. Retrieved February 2, 2020, from http://ec.europa.eu/transport/themes/sustainable/studies/doc/2014-handbook-external-coststransport.pdf.

[13] Jayasioriya, S.A.C. \& Yapa, M.B. (2017). Measuring the economic cost of traffic congestion. Retrieved November 18, 2019, from http://www.researchgate.netlpublications/318473826.

[14] Grant-Muller, S. \& Laird, J. (2007). International literature review of the costs of road traffic congestion. Scottish executive. Retrieved July 18, 2020, from www.scotland.gov.uk/Publications/2006/11/01103351/0.

[15] OECD/ECMT. (2007). Managing urban traffic congestion, economic co-operation and development (OECD) and European conference of transport Ministers (ECMT), Retrieved July 17,2020, from www.internationaltransportforum.org/Pub/pdf/07Congestion.pdf.

[17] World health Organization, (2009). WHO guide to identifying the economic consequences of disease and injury. Department of Health Systems Financing Health Systems and Services working document 2009.

[18] Ogwude, I.C. (1998). Valuation of reduction in traffic accidents. The trainer: Journal of the institute of transport and logistics, Zaria, June-September, 18-27. 